\title{
Accounting and Management of Zakat, Infak/ Sedekah (Case Studies of Zakat Institutions in Medan City)
}

\author{
Nurlinda $^{1}$, Muhammad Zuhirysan ${ }^{2}$, Fajri Salimi ${ }^{3}$, Zulkifli Umar ${ }^{4}$, Mulyadi $^{5}$, Josi Farmiati $^{6}$ \\ Department of Accounting, Politeknik Negeri Medan, Medan, Indonesia ${ }^{1}$ \\ Department of Accounting, Politeknik Negeri Medan, Medan, Indonesia ${ }^{2}$ \\ Department of Financial Analysis, Politeknik Kutaraja, Banda Aceh, Indonesia ${ }^{3}$ \\ Department of Accounting, Universitas Muhammadiyah Aceh, Banda Aceh, Indonesia ${ }^{4}$ \\ Department of Accounting, Universitas Muhammadiyah Aceh, Banda Aceh, Indonesia ${ }^{5}$ \\ Department of Office Administration, Politeknik Kutaraja, Banda Aceh, Indonesia ${ }^{6}$
}

\{nurlinda@polmed.ac.id\}

\begin{abstract}
This study aims to determine the role of the application of zakat, Infaq / Sadaqah (ZIS) accounting in the management of ZIS in ZIS management institutions so that the contribution of ZIS to improve community welfare is achieved. This research was conducted at the ZIS management institution in Medan City. The study also looks at whether the ZIS management agency regulates the preparation of financial reports as a medium of accountability for its operational activities. This study uses questionnaires and interviews in collecting data. The research sample was the management staff of Amil and ZIS from the ZIS management institution in the city of Medan. The results showed that subjective attitudes and norms had no effect on interest in managing ZIS using PSAK 109.
\end{abstract}

Keywords: ZIS, Zakat, PSAK 109

\section{Introduction}

The order for Muslims to fulfill ZIS is found in Al-Qur'an Al-Baqarah verse 43 which means "Stand up prayer, lift up Zakat, Infak/ Sedekah and bow down with those who prostrate themselves" and the Qur'an at At-Taubah verse 103, which means following "Take Zakat, Infak/ Sedekah from their property, to clean and purify them ... "[1]. From an economic and social perspective, ZIS is intended to achieve social justice. [2][3] concerning the management of ZIS is a form of support from the Indonesian government in the management of ZIS (ZIS) funds. The purpose of this law is as a legal umbrella for the establishment of a ZIS management organization in Indonesia so that ZIS management organizations can carry out their functions in accordance with religion and the State. This law regulates ZIS management functions under the National ZIS Agency (BAZNAS) which is the parent organization for all ZIS management organizations including BAZIS, LAZIS, LAS and others, where all these organizations are asked to report on implementation, collection, distribution, and development of ZIS regularly audited [4]

Muzaki and Munfiq were due to a lack of transparency in the report on the use of ZIS funds managed by Amil to the public. Therefore, the rules for reporting the use of funds apply 
to all Amil in Indonesia [5]. Accountable management demands also address the problems that arise in financial management at BAZIS / LAZIS, namely: 1) Bazis' financial statements are still simple and not uniform [6]; 2) BAZIS financial managers do not yet know the rules regarding published financial reporting; 3) Many BAZIS owned by local governments and private governments publish their reports only on the basis of expenditure and so on, so that in financial reports such as recognition of cash basis accounting [7] in practice ZIS funds only affect these income Cash events also affect ZIS balances [8]; 4) There are BAZIS who report their financial position only in the form of a balance sheet where ZIS funds, infaq funds, amil funds, and non halal funds are mixed into one. This mixing is a very difficult obstacle when a financial audit is carried out. Furthermore, mixed funds have an impact on the difficulty of managing funds because they are amil funds and portion funds; 5) Another problem arises when BAZIS recognizes ZIS funds, infaq / shadaqah funds, and non-halal funds but does not include amil funds [9]; 6) Human resources holding the same position so that BAIS is only used as a side job [10]. This problem ultimately questions how high-level managers are in applying financial report standards. Even the ZIS organization and infaq/sadaqah management still apply conventional accounting, while the current entity must be accountable, transparent and professional to the public [5].

Financial statements that are said to be accountable and transparent when typing financial statements are prepared based on applicable financial accounting standards [11]Thus the BAZIS institution which is the main activity in managing ZIS, in the preparation of financial statements using PSAK No. 109.concerning Zakat and infaq / shadaqah. However, as good as the standards or regulations compiled about depending on the behavior of the ZIS management entity. One behavior is related to the manager's interests and also based on subjective attitudes and norms.

\subsection{Attitudes, Subjective Norms, Interest in the Application of PSAK No. 109}

Agency theory arises when there is information asymmetry obtained by the principla agent. The agent relations arise when principals work with agents, where principla will provide facilities and delegate authority and decision-making policies to agents [12]. In agency relationships, agents must provide periodic reports about their performance to the principal, and then the principal will assess the performance of the agent based on the financial statements submitted [13]. In the management of ZIS there are two parties who have a common interest, Muzakki acts as the principla and ZIS management organization as an agent. The Principla hopes that the agent will manage the ZIS funds that are stored in accordance with sharia and the applicable provisions.

The attitude comes from intention, the intention is the subjective probability of the individual in making choices on various behavioral alternatives [14]. Individual intention to conduct behavior according to planned behavior theory (TPR) or theory of action reasoning (TTB) is determined by three independent factors (Ajzen 1985; 1991) in [14] The first factor is the attitude towards behavior. Attitudes toward behavior are constructs that combine a person's beliefs about the possibility of certain outcomes from behavioral outcomes (also known as behavioral beliefs) and an overall evaluation by someone of these results. According to this theory, individuals who believe in applying certain behaviors will cause positive results, so they will have an attitude that supports the implementation of this behavior. Attitude refers to a positive or negative attitude towards the application of ZIS accounting. Attitudes related to evaluating beliefs or feelings related to the application of ZIS accounting practices which consist of recognition, measurement, presentation, and disclosure[15]. in the ZIS organization. 
The items measured include statements originating from PSAK No. 109. Pujianto found that attitudes towards ZIS accounting practices did not partially influence the interest of amil in applying ZIS accounting practices [4].

Subjective norms show the individual's beliefs about social pressure to do or not conduct behavior (also known as normative beliefs). Subjective norms are constructs that combine individual beliefs in certain references and the motivation of someone to comply with their references. Thus, the higher a person's trust in the referral, the more confident the behavior is needed and the higher one's compliance with the referral, the higher the person's tendency to carry out certain behaviors. Subjective norms show the individual's beliefs about social pressure to do or not conduct behavior (also known as normative beliefs). The research found that subjective norms of ZIS accounting practices and infaq/shadaqah partially influence the interests of amil/ ZIS Managers in applying ZIS accounting practices [4].

The perceived interest or behavioral control (perception of behavioral control) is interpreted as a person's beliefs about the level of difficulty/ease of behavior (also called control belief) (Ajzen 1991) in [14], or the level of authority given to someone to do behavior (Carpenter and Reimers 2005) in [14]. Interest is the desire to do behavior [16]. Referring to this theory, the higher the level of authority a person has to do a certain behavior, the easier it is for that person to do it. Interest is the desire to do behavior [16]. Interest is the evaluation of positive or negative individual amil zakat on the application of accounting practices of zakat and infaq/ sedekah. while subjective norms are stakeholder perceptions in ZIS management organizations that influence interest in applying or not applying ZIS accounting practices [4]. The application of ZIS accounting is an interest in the application of ZIS accounting practices. This interest is related to the desire of amil to apply accounting which consists of the practice of recognizing, measuring, presenting and accounting for ZIS in ZIS management institutions. This variable is measured based on the reports listed in ZIS financial accounting, namely PSAK 109.

The results of several studies indicate that the overall preparation of ZIS management financial statements has not applied PSAK Number 109 [17][5] [7][18] [19] [20] [21], while (Yulyani, 2012) found that the financial statements of ZIS management organizations are in accordance with PSAK Number 109[4]. The differences in the results of this study indicate that there are different behaviors in financial management in ZIS institutions

\section{Method}

The population in this study was Amil and staff of the financial division of the ZIS manager in the city of Medan. The sample in this study was amil and the staff of the financial division of ZIS management in Medan city. Given that there is no definite population, the sample from this study is 96 samples. The sampling method in this study used non-probability because the population studied was Infinite and convenience sampling. ZIS management which tends to be closed causes 96 respondents, only 31 samples can be collected and used to manage data in this study. The data was collected through a questionnaire, and data was measured using a 1 to 5 Likert scale, consisting of 1 . SS (strongly agree); 2. S (agree); 3 . N (neutral); 4.KS (disagree); 5. TS (disagree). The variables of this study consisted of Attitude variables (X1), subjective norm variables (X2) and Interest variables on the application of PSAK 109 (Y), and data were processed using multiple linear regression with SPSS tool. 


\section{Result and discussion}

The results of the statistical description in table 3.1 show information relating to attitude variables and subjective norms. Variables that have the lowest average value are attitudes equal to 49 or equal to $31.61 \%$ while the highest average value is the interest variable of 130 or $83.87 \%$. Referring to the data in the table, it can be seen that the average value of interest variables shows a number that exceeds subjective attitudes and norms. Thus it can be concluded that the joint attitude variable, subjective norms support the interest of amil in applying PSAK 109 to ZIS management. This conclusion is based on the average interest rate of $83.87 \%$ which is above the average value of other variables. For more details, see table 3.1

Table 3.1 Characteristics of Research

\begin{tabular}{lccccc}
\hline \multicolumn{1}{c}{ Variable } & Minimum & Maximum & $\begin{array}{c}\text { Total } \\
\text { Score }\end{array}$ & \% Lowest & \% Highest \\
\hline Attitude & 49 & 103 & 155 & 31,61 & 66,45 \\
\hline Subjektive Norms & 65 & 111 & 155 & 41,94 & 71,62 \\
\hline Interest & 79 & 130 & 11 & 50,97 & 83,87 \\
\hline
\end{tabular}

All instruments state valid. Reliability test shows all variables declared reliable. The normality test also shows that all variables meet the classical assumption test and the data is feasible for regression testing. Partial influence between the dependent variable and the independent variable can use $\mathrm{t}$ count and significance of the calculated $\mathrm{t}$ value. If the significance value of $t$ is smaller than $\alpha(5 \%)$, it can be stated that there is an influence of the independent variable on the dependent variable.

Table 3.2 1Statistical Test Results

\begin{tabular}{l|c|c|c|c|c}
\hline \multicolumn{1}{c|}{ Variable } & Koefisien B & t count & t table & Sig & Result \\
\hline Attitude & 0.213 & 0.820 & 2.045 & 0.419 & Not significant effect \\
\hline Subjektive Norms & 0.512 & 1.973 & 2.045 & 0.058 & Not significant effect \\
\hline
\end{tabular}

The test results in table 3.2 show partially that it can be interpreted that when attitude increases it will not affect the increase in interest. In this study, it appears that attitude is not one of the factors that influence the interest of amil/ ZIS managers in applying PSAK 109. This attitude variable refers to the attitude of amil/ ZIS managers towards the acceptance of financial reporting standards in the form of PSAK 109 which includes managerial / amil attitudes for recognition, measurement and disclosure.

\subsection{The Effect of Attitudes towards Interest in Applying PSAK 109}

The following table 3.3 shows how the attitude of amil /ZIS managers towards the recognition, measurement and disclosure of ZIS. 
Table 3.3 Review Indicator of Attitude variables in Applying PSAK 109

\begin{tabular}{l|c|c|c|c}
\hline \multicolumn{1}{c|}{ Indicator } & Total instrument & Total score & $\begin{array}{c}\text { Standard } \\
\text { Score }\end{array}$ & $\%$ \\
\hline Recognition & 10 & 1,221 & 1550 & 78.77 \\
\hline Measurement & 2 & 240 & 310 & 77.42 \\
\hline Presentation and Disclosure & 8 & 1,069 & 1,240 & 86.21 \\
\hline Total statement & 20 & & & \\
\hline
\end{tabular}

We review each indicator and group it into 3 sections consisting of the attitude of the amil / ZIS managers on their understanding of PSAK 109 which consists of attitudes towards recognition, measurement and presentation and disclosure. Table 5.3 shows that the attitude of the amil / ZIS manager was very low in measurements which showed that the total score was only $77.42 \%$. Indicators related to measurement consist of how Amil/ ZIS managers behave in determining the fair value of managed ZIS and measurement of asset value reduction. We found that out of a total of 31 respondents we interviewed, only 4 had received information about PSAK 109 or $12.9 \%$ while the remaining $87.1 \%$ had never received socialization regarding PSAK. Although the amil / ZIS manager has a good level of education but the understanding of ZIS management standards is inadequate. Our guess is that ZIS managers are not those who have special economic or accounting education. In the interviews we conducted we found that respondents did not really understand the indicators of the statements we prepared by adopting points from the statement of PSAK 109. Here we conclude that our respondents were not all economically educated, especially accounting. This accusation needs to be studied further in the next study considering that in our questionnaire, we did not include choices regarding the respondents' educational subjects.

Regarding the attitude of the amil / ZIS manager in recognition, the total score was $78.77 \%$. This figure is also low given the difficulty of respondents' interpretations of indicators regarding ZIS cash receipts and non-cash receipts, recognition of how much Muzaki acknowledges if ZIS is received in cash or non-cash, recognizes the amount of ZIS if Muzaki has Mustahik, recognition of asset damage -set ZIS if caused by amil negligence or not due to amil negligence, recognition of ZIS distribution to mustahik in cash and non-cash, ZIS recognition is distributed to amil and also distribution of infaq / alms by amil to other amil, recognition of fixed assets is left to the management of other parties without controlled by amil, and recognition of infaq / sadaqah funds if managed before being distributed. Lack of socialization caused respondents to be unfamiliar with the provisions contained in PSAK 109.

The attitude indicator about presentation and disclosure shows a pretty good number of $86.21 \%$. The indicator section related to presentation and disclosure is the attitude of Amil / ZIS manager statements regarding the separation of ZIS funds and amil funds in the statement of financial position, disclosure of ZIS distribution policies for non-amil and musthik, disclosure of fair value determinants for non-cash ZIS assets, disclosure of details distribution and ZIS for mustahik, disclosure of ZIS use in the form of productive assets controlled by amil or other parties, disclosure of relations with related parties between amil and mustahik, disclosure of infaq / sadaqah previously managed with good percentage, disclosure separately from ZIS management, disclosure of the existence of non-halal funds, disclosure of amil's performance and presentation of related reports other than the financial position of the report such as reports of changes in funds, changes in assets in managing cash flow statements and 
notes to financial statements. For this indicator, the value is quite good, especially regarding policies, halal and non-halal separation, but related to financial reporting, the value is not significant.

Based on the above review, we conclude that lack of knowledge and lack of socialization and training have led to amil / ZIS managersattitudes not affecting the interests of amil / ZIS managers in implementing PSAK 109 especially if there are no sanctions for institutions managing ZIS and not applying PSAK 109 interest in apply PSAK 109 to manage ZIS. The results of this study support the Pujianto [21] study which found no influence on attitudes toward interest in applying PSAK 109.

\subsection{The Effect of subjective norms on interest in applying PSAK 109}

The results of this partial test can be interpreted that when subjective norms increase it will not affect the increase in interest. In this study it can be seen that subjective norms are not one of the factors that influence the interest of amil / ZIS managers in applying PSAK 109. Subjective norms are variables that show the views or perceptions of ZIS managers on the practice of applying PSAK 109 related to their perceptions of stakeholder expectations or desires the interests of the ZIS organization for good ZIS governance. Perception on the desire to provide good management of ZIS is expected to influence the interest of ZIS managers to choose to implement accounting practices in accordance with the standards for the management of ZIS. The subjective norm of ZIS managers in the form of acceptance in the implementation of accounting practices consisting of recognition, measurement, presentation and disclosure is the basis of the increasing interest of ZIS managers to apply accounting practices about ZIS.

Our analysis of indicators that form subjective norm variables shows that subjective norms in the form of perceptions that influence interest are shown in table 3.4. The same results obtain subjective norms with attitude variables where the weakest indicators are contributed by indicators that build measurements that show the number 240 or $77.42 \%$

Table 3.4 2Review indicators of Subjective Norm Variables in Applying PSAK 109

\begin{tabular}{l|c|c|c|c}
\hline \multicolumn{1}{c|}{ Indicator } & Total instrument & Total score & $\begin{array}{c}\text { Standard } \\
\text { Score }\end{array}$ & $\%$ \\
\hline Recognition & 10 & 1,255 & 1550 & 80.97 \\
\hline Measurement & 2 & 240 & 310 & 77.42 \\
\hline Presentation and Disclosure & 11 & 1,426 & 1,705 & 83.64 \\
\hline Total statement & 23 & & & \\
\hline
\end{tabular}

These results further reinforce our suspicion that respondents do not have sufficient understanding and knowledge of how accounting practices, especially in measuring income in the form of non-current assets, are included in the process of how to measure if there is a decrease in asset value and depreciation. The successful acceptance of accounting practices is very dependent on the understanding of Amil/ ZIS managers. The higher the Amil/ ZIS manager understands and easily applies ZIS accounting practices in accordance with PSAK 109, the stronger the interest of ZIS managers in applying PSAK 109.

For subjective norm indicators related to recognition and presentation and disclosures, the numbers were quite good at $80.97 \%$ for recognition and $83.64 \%$ for presentation and disclosure. This indicator shows the perceptions and desires of Amil / ZIS managers to be 
subjectively willing to follow the rules stated in the accounting standards of PSAK 109 . We conclude that the Amil / ZIS managers have the desire to implement PSAK 109 but due to limitations especially due to lack of socialization training and lack of knowledge of PSAK 109 plus the Amil / ZIS manager does not fully have economic or accounting education which causes Amil's / ZIS manager's lack of interest in applying PSAK 109. The conclusion that ZIS managers have no economic education is found in our interview list, where on the indicators of presentation and disclosure, statement instruments that support this indicator are related to the presentation and disclosures in the ZIS report. The percentage of $78.60 \%$ indicates that the respondents were not interested because of the lack of understanding of the report produced in accordance with PSAK 109.

Tabel 3.5Reviu Indicators of Interest Variables in Applying PSAK 109

\begin{tabular}{|c|c|c|c|c|}
\hline Indicator & $\begin{array}{c}\text { Total } \\
\text { instrument }\end{array}$ & $\begin{array}{l}\text { Total } \\
\text { score }\end{array}$ & $\begin{array}{c}\text { Standard } \\
\text { Score }\end{array}$ & $\%$ \\
\hline Recognition & 12 & 1,589 & 1,860 & 85.43 \\
\hline Measurement & 2 & 240 & 310 & 82,87 \\
\hline Presentation and Disclosure & 12 & 1,426 & 1,860 & 78,60 \\
\hline Total statement & 26 & & & \\
\hline
\end{tabular}

Based on table 3.5, it can be concluded that there is no influence of subjective norms on the interests of Amil / ZIS managers in applying accounting practices in accordance with the standards of PSAK 109. The results of this study are inconsistent with Pujianto [21] who find that there is an influence of ZIS manager subjective norm interest in applying PSAK 109.

\section{Conclusion}

This study found that subjective and partial attitudes did not affect the interest of ZIS managers in applying PSAK 109 to ZIS management organizations in Medan, but simultaneously subjective attitudes and norms had a significant influence on the interests of ZIS managers in applying PSAK 109 to ZIS management. organization in the city of Medan. The research sample collected was very small from the total sample counted, this was because the collection time was limited and there were ZIS managers who refused to fill out the questionnaire on the grounds that they did not want to understand PSAK 109.

The research sample collected is very small from the number of samples calculated, this is because the collection time is limited and there is aAmil/ ZIS manager who refuses to fill out the questionnaire on the grounds that he does not want to understand PSAK 109. For further research, can add information about the type of Amil/ ZIS manager education, so that later it can be the basis that Amil/ ZIS managers must be those who understand ZIS management practices in an accounting manner. For IAI, socialization and training for ZIS managers must be carried out, of course, at a low cost considering that this non-profit institution is very sensitive to the governance associated with ZIS. 


\section{References}

[1] Departemen Agama, Alquran dan Terjemahannya. Jakarta: Departemen Agama Republik Indonesia, 2002.

[2] P. R. Indonesia, Undang-Undang Nomor 23, Tentang Pengelolaan Zakat. 2011.

[3] A. Rosadi, D. Effendi, and B. Busro, "The Development of Waqf Management Throught Waqf Act in Indonesia (Note on Republic of Indonesia Act Number 41 of 2004 regarding Waqf)," Madania J. Kaji. Keislam., vol. 22, no. 1, p. 1, Jul. 2018.

[4] P. Pujianto and A. Asrori, "Implemantasi PSAK 109 Pada Organisasi Pengelola Zakat dan Infak/ Sedekah di Kota Semarang," Account. Anal. J., vol. 4, no. 1, pp. 1-9, 2015.

[5] Istutik, “Analisis Implementasi Akuntansi Zakat Dan Infak/Sedekah (PSAK:109) Pada Lembaga Amil Zakat Di Kota Malang,” J. Akunt. Aktual, vol. 5, no. 1, 2013.

[6] Y. Wibisono, "Potensi Zakat Nasional: Peluang dan Tantangan Pengelolaan," in Seminar Nasional Zakat, 2016.

[7] Fathonah, "Analisis Penerapan Akuntansi Zakat Pada Organisasi Pengelola Zakat (Studi Kasus LAZISMU Kabupaten Klaten dan BAZDA Kabupaten Klaten)," Universitas Islam Negeri Sunan Kalijaga, 2013.

[8] Mohd Asri Mohd Ali, M. D. A. B. K. Tazilah, A. I. Bin Shamsudin, F. R. B. F. Shukri, N. M. F. A. B. N. Adelin, and W. M. S. B. W. Z. Zaman, "Factors That Influence The Zakat Collection Funds: A Case In Kuantan, South East Asia," South East Asia J. Contemp. Business, Econ. Law, vol. 13, no. 1, pp. 30-37, 2017.

[9] N. Ipansyah, N. Rahmi, and R. Helmi, "Studi Penerapan Akuntansi Zakat pada BAZNAS Provinsi Kalsel dan BAZNAS Kota Banjarmasin," TASHWIR, vol. 1, no. 1, Sep. 2014.

[10] M. Sularno, "Pengelolaan Zakat Oleh Badan Amil Zakat Daerah Kabupaten / Kota Se Daerah Istimewa Yogyakarta (Studi terhadap Implementasi Undang-Undang No.38 Tahun 1999 Tentang Pengelolaan Zakat)," La_Riba, vol. 4, no. 1, pp. 35-45, Jul. 2010.

[11] Nurlinda, “Akuntabilitas Pengelolaan Keuangan Desa,” J. Ris. Akunt. Keuang, vol. 6, no. 1, pp. 1705-1714, 2018.

[12] M. C. Jensen and W. H. Meckling, "Theory of the firm: Managerial behavior, agency costs and ownership structure," J. financ. econ., vol. 3, no. 4, pp. 305-360, Oct. 1976.

[13] M. Iqbal, T. Sutrisno, and P. R. Assih, "Effect of Environmental Accounting Implementation and Environmental Performance and Environmental Information Disclosure as Mediation on Company Value," Int. J. Bus. Manag. Invent., vol. 2, no. 10, pp. 55-67, 2013.

[14] N. Nurofik, "Pengaruh sikap, norma subyektif, dan kontrol perilaku pada pengungkapan tanggung jawab sosial," J. Akunt. Audit. Indones., vol. 17, no. 1, pp. 43-56, Jun. 2013.

[15] Dewan Standar Akuntansi Keuangan, Standar Akuntansi Keuangan. Jakarta: Salemba Empat, 2016.

[16] Jogiyanto, Sistem Informasi Keperilakuan. Yogyakarta: ANDI Publisher, 2007.

[17] A. Muslih, "Penerapan Akuntansi Zakat, Infaq/ Shadaqoh Berdasarkan PSAK No. 109 pada LAZ Rumah Zakat Malang," Universitas Islam Negeri Maulana Malik Ibrahim, 2015.

[18] Setiariware and A. Metari, "Analisis Penerapan Akuntansi Zakat, Infak dan Sedekah pada LAZ (Lembaga Amil Zakat) Dompet Dhuafa Cabang Makasar)," Universitas 
Hasanuddin, Makassar, 2013.

[19] R. Indrayani, I. Yuningsih, and Salma Patitisahusiwa, "Analisis Perlakuan Akuntansi Zakat, Infaq dan Shodaqoh Pada Lazis Dana Peduli Ummat (LAZ DPU) Di Samarinda," Universitas Mulawarman, 2012.

[20] A. K. Prasetyoningrum and U. K. Umah, "Penerapan Akuntansi Zakat pada Lembaga Amil Zakat (Studi pada LAZ DPU DT Cabang Semarang)," Value Added Maj. Ekon. dam Bisnis, vol. 7, no. 2, pp. 68-97, 2011.

[21] Pujianto, Implementasi PSAK 109 Tentang Akuntansi Zakat dan Infak/Sedekah. Semarang: Universitas Negeri Semarang, 2015. 